\title{
GOBERNAR MEDIANTE DECRETO-LEY EN ESPAÑA: CUANDO LA EXCEPCIÓN SE CONVIERTE EN NORMA
}

\author{
Ruling by decree-laws in Spain: \\ When the exception becomes the rule
}

Pedro Brufao Curiel*

Universidad de Extremadura

Cáceres, España

* Doctor en Derecho Administrativo por la Universidad Carlos III de Madrid y LLM in Energy and Environmental Law por la Tulane University Law School de Nueva Orleans. Profesor Contratado Doctor de la Universidad de Extremadura. Cáceres, España. Correo electrónico: pbrufao@unex.es.

Artículo recibido el 22 de marzo de 2018 y aceptado para publicación el 31 de mayo de 2018. 
RESUMEN: Los sistemas jurídicos occidentales contemporáneos poseen como una de sus características esenciales el que el poder legislativo recaiga en las Cámaras representativas elegidas por sufragio. Estas son las encargadas de aprobar las diversas leyes que, con ánimo de generalidad, regulen las distintas materias que afectan a la sociedad. Sin embargo, en ocasiones extraordinarias, el poder ejecutivo goza de la prerrogativa de aprobar normas reglamentarias con fuerza de ley. De modo progresivo tanto el Gobierno central como algunas Comunidades Autónomas españolas han recurrido cada vez más a esta figura, soslayando así las funciones del Parlamento, lo que desdibuja la necesidad de acudir a este tipo de normas reglamentarias en casos excepcionales. En este trabajo se analizará el caso español mostrando ejemplos concretos.

Palabras Clave: decretos-leyes, fuentes del derecho, división de poderes, España.

ABSTRACT: Within Western legal regimes, our legal tradition shows us that legislative power rests in the Parliaments elected by suffrage, which are in charge of passing acts that, aiming at a general scope, address several matters that lie in society's interest. Notwithstanding, executive power holds in extraordinary occasions the right to pass statutory rules having force of law. Both Spanish national government and regional ones have increasingly approved this kind of decrees, and thus have ignored the parliamentary duties by passing decree-laws which blur the requirement of facing extraordinary situations. In this paper, we will show the Spanish case with some real examples.

KEYWORDS: Decree-laws, sources of the law, separation of powers, Spain. 


\section{INTRODUCCIÓN}

El sistema jurídico político dominante en los países de cultura occidental establece la división de poderes como uno de sus pilares fundamentales, cada uno con una función específica por todos conocidas: legislar, ejecutar las normas y juzgar.

Desde el punto de vista del análisis de las fuentes del Derecho, las normas con rango de ley emanan de los distintos parlamentos. Sin embargo, se prevé constitucionalmente que en situaciones concretas el poder ejecutivo dicte normas reglamentarias con fuerza de ley.' Estas situaciones concretas, excepcionales, en las que la Constitución permite que el gobierno publique reglamentos con fuerza de ley, se han interpretado en España de manera muy laxa, haciendo que, en realidad, la excepción se convierta sino en regla al menos en una situación muy acostumbrada. Es más, incluso ha habido ocasiones en que el Parlamento español le ha pedido al Gobierno de la Nación que dictase decretos-leyes, declinando así y renunciado a sus propios poderes.

Esta situación no es sino una muestra del debilitamiento progresivo del Parlamento a favor de la acción gubernamental, fenómeno que a su vez implica consecuencias jurídicas nada desdeñable, como la imposibilidad de recurrir ante los tribunales administrativos ordinarios normas que materialmente son reglamentos, e incluso actos administrativos, o la elusión del debate parlamentario sobre materias con fuerza de ley.

En este trabajo veremos los detalles de esta situación respecto de los decretos-leyes nacionales, ${ }^{2}$ enfatizando la laxa interpretación del Tribunal Constitucional español y la numerosa casuística de esta situación, que ha sido subrayada con preocupación por la mejor doctrina jurídica.

1 Como también se recogen en el artículo 64 de la Constitución de la República de Chile, que contrasta con la figura recogida en la Constitución Española de 1978.

2 No así de los emanados de los Gobiernos de las Comunidades Autónomas. Vid. González García (2017). pp.99-124. 


\section{NATURALEZA Y RÉGIMEN JURÍDICO DEL DECRETO LEY}

Como ha recogido la doctrina española ${ }^{3}$ el decreto ley es "toda norma con rango de Ley que emana, por vía de excepción, de un órgano que no tiene el poder legislativo, concretamente del Gobierno o del Consejo de Ministros". La nota de la excepcionalidad es la clave en este tipo de norma, basada en el estado de necesidad ${ }^{4}$ y en la satisfacción y protección de la "salud pública" en su más amplio sentido, razón por la cual el iter procedimental de aprobación de las normas y el respeto a las competencias de quien ha de aprobarlas cede ante la conservación de un orden social que no puede quedar al albur de la aprobación de una ley.

Asimismo, también se ha argumentado que en estos casos urgentes es el Gobierno el que asume las potestades parlamentarias mediante su traslación oportuna al poder ejecutivo, según la figura civilista de la negotiorum gestio, o también se ha defendido la tesis de una suerte de delegación tácita del Parlamento para el Gobierno cuando no puede esperarse a la compleja, lenta e incluso tardana serie de actos parlamentarios que conducen a la aprobación de una ley. ${ }^{5}$ La verdad es que en nuestro sistema constitucional moderno trae causa del devenir histórico del parlamentarismo revolucionario francés, el cual hizo hincapié en la ley general aprobada en la Asamblea como instrumento jurídico genuino, ${ }^{6}$ aunque como los hechos demostraron posteriormente, el Gobierno no desdeñaría la posibilidad de asumir potestades atribuidas en principio al poder legislativo, sin apoyo doctrinal ni constitucional expreso o a través de meras autorizaciones parlamentarias o sometidas a cierto control posterior.

No obstante lo anterior y de modo independiente del debate doctrinal existente, hemos de acudir al artículo 86 de la Constitución Española de 1978 (en adelante CE) que es el que recoge esta fuente del Derecho en el Capítulo segundo ("De la elaboración de las leyes") del Título III ("De las

3 García de Enterría y Fernández (2002) p. 142.

4 Sobre el estado de necesidad, su concepto, objeto y condiciones, recomiendo la atenta consulta de Álvarez García (1996).

5 García de EnterRía recoge también la tesis de la ratificación, gracias a la cual la actividad gubernamental sería ilícita, pero se convalidaría a posteriori por el Parlamento.

6 Como resume MuÑoz MACHADO (2006) pp. 636 y siguientes. Este autor nos muestra la historia constitucional en este sentido llevada a cabo en Francia, Italia y España. 
Cortes Generales"): "1. En caso de extraordinaria y urgente necesidad, el Gobierno podrá dictar disposiciones legislativas provisionales que tomarán la forma de Decretos-leyes y que no podrán afectar al ordenamiento de las instituciones básicas del Estado, a los derechos, deberes y libertades de los ciudadanos regulados en el Título I, al régimen de las Comunidades Autónomas ni al Derecho electoral general. 2. Los Decretos-leyes deberán ser inmediatamente sometidos a debate y votación de totalidad al Congreso de los Diputados, convocado al efecto si no estuviere reunido, en el plazo de los treinta días siguientes a su promulgación. El Congreso habrá de pronunciarse expresamente dentro de dicho plazo sobre su convalidación o derogación, para lo cual el reglamento establecerá un procedimiento especial y sumario. 3. Durante el plazo establecido en el apartado anterior, las Cortes podrán tramitarlos como proyectos de ley por el procedimiento de urgencia".

Su interpretación literal lleva a subrayar sus elementos definidores que lo apartan de una mera alternativa u opción a emplear por la sola voluntad del poder ejecutivo, destacando las relativas a las circunstancias de su aprobación: la situación fáctica o presupuesto de hecho habilitante de la necesidad o lo perentorio de la acción administrativa; que esta sea extraordinaria y urgente; su provisionalidad y el que no puedan afectar al núcleo esencial de nuestro ordenamiento e instituciones. Esta situación excepcional va de suya pareja a las circunstancias de provisionalidad y a su inmediato sometimiento a debate parlamentario en la totalidad de su redacción sin que quepa obviar tal obligación de revisión del presupuesto del hecho habilitante si la Cámara Baja no estuviera reunida en el período de sesiones. Se ve también que el Congreso de los Diputados conserva su poder de aprobación legislativa al poderlos tramitar como proyectos de ley por el procedimiento de urgencia.

El acuerdo o acto de convalidación no altera la naturaleza jurídica de los decretos-leyes, ${ }^{7}$ pues como se afirmó en el primer fallo constitucional que decidió sobre la materia, la Sentencia del Tribunal Constitucional (en adelante STC) $n^{0}$ 29/1982, de 31 de mayo, estas normas se aprueban como una excepción al procedimiento ordinario y siguen gozando de la

7 Con algunas contribuciones tempranas de la doctrina administrativista: SORIANO García (1983) pp. 453-470. Este autor destaca los vaivenes de la primera jurisprudencia constitucional y se centra sobre todo el concepto de la "urgencia" y su control judicial. 
naturaleza de la norma reglamentaria hasta que se publique la ley ordinaria que pueda sustituirlas, mientras que la STC no 6/1983, de 4 de febrero, la segunda sentencia de la jurisprudencia constitucional recaída sobre el particular recoge sobre este punto su naturaleza jurídica según lo dicho en la primera y afirma: "debemos recordar la doctrina establecida ya en nuestra Sentencia de 31 de mayo de 1982. La convalidación que el Congreso de los Diputados puede realizar de un Decreto-ley no produce una sanción del mismo, si éste fuera originariamente nulo por haberse producido con extralimitación, pues la «sanción» sólo podría producirse mediante su transformación en Ley una vez seguida la correspondiente tramitación parlamentaria. Lo que el artículo 86.2 de la CE llama «convalidación» es más genuinamente una homologación respecto de la existencia de la situación de necesidad justificadora de la iniciativa normativa encauzada por ese camino. La mencionada Sentencia señaló también que corresponde a este Tribunal el examen de la constitucionalidad o inconstitucionalidad formal de la norma, lo que ha de realizarse a través de dos vías: el ajuste de la misma en concreto a la relación genérica de materias que el Decreto-ley puede comprender; y la observancia de la relación de adecuación entre la respuesta normativa dada a la situación motivadora y la urgencia que la justificó, pues, aunque la observancia de los límites genéricos del artículo 86 de la CE pueda haber existido y el Congreso de los Diputados puede haber homologado el Decreto-ley siempre tendrá que ser la respuesta normativa adecuada congruentemente con la situación de necesidad alegada como título habilitante de la puesta en marcha de esta fuente del Derecho". ${ }^{8}$

Lo que se acaba de transcribir tiene su importancia en cuanto a la validez de los efectos producidos por un decreto o acto nulo por haber incurrido en una extralimitación que no puede sanar la convalidación parlamentaria, cuestión diferente de que el contenido del decreto-ley pueda recibirse por

8 Vid. asimismo la sentencia del Tribunal Constitucional Español: recurso de inconstitucionalidad no 116/1983, promovido por José Ruiz Gallardón, contra Real Decreto-ley $n^{\circ}$ 2/1983 sobre expropiación (1983, sentencia $\mathrm{n}^{\mathrm{O}} 111 / 1983$ ) y recursos de inconstitucionalidad acumulados $\mathrm{n}^{\circ}$ 2.548/92 y n ${ }^{0}$ 553/93, promovidos por Federico Trillo-Figueroa Martínez-Conde, contra los artículos 2 y 6.1 del Real Decreto-ley $n^{\circ}$ 5/1992, de 21 de julio, de Medidas Presupuestarias Urgentes y art. 2 de la Ley $n^{o}$ 28/1992 (1987, sentencia $\left.n^{0} 182 / 1997\right)$. Esta última recoge en su fundamento jurídico primero en cuanto a su tramitación como proyecto de ley y eventual aprobación como ley ordinaria que "ni la eventual falta de impugnación de la Ley posterior ni la derogación por ésta del Real Decreto-ley puede ser nunca óbice para el examen por parte de este Tribunal de los motivos formales de inconstitucionalidad esgrimidos contra el Real Decreto-ley". 
una eventual ley ordinaria tras el trámite parlamentario oportuno, cuya nulidad es distinta y cuenta con efectos y procedimientos de nulidad diferentes, es decir, no hay una comunicación de la nulidad del decreto-ley a la de la ley ordinaria posterior ya que no se prevé en la Constitución y son instrumentos normativos muy distintos la ley y el decreto-ley. ${ }^{9}$

No obstante lo anterior, la actividad legislativa vía decreto-ley ha sufrido un empleo calificado de abusivo por gran parte de la doctrina, ${ }_{10}^{10}$ gracias al cual se ha extendido la apreciación del supuesto de hecho habilitante y las circunstancias que justifican su uso excepcional, ya sea por contar con la alternativa del procedimiento legislativo de urgencia, no contemplar el decreto ley los fines para cuya consecución se aprobó, no concretarse la urgencia y deslegalizar materias sin plazo, prolongarse en el tiempo situaciones objeto del decreto ley que se extralimitan en su provisionalidad inherente o afectar a las materias excluidas por el artículo 86 de la CE con una vis expansiva que ha roto las costuras de esta figura, materias excluidas que abarcan prácticamente aquellas que han de regularse mediante ley orgánica. En las páginas siguientes repaso con espíritu crítico tanto la creciente abundancia del recurso al decreto-ley como manera nada extraordinaria de legislar ${ }^{11}$ como la cambiante jurisprudencia constitucional por la que se ha refrendado la actividad gubernamental.

9 SOriano García(1983) p. 464. Este autor tilda en la página siguiente de "abuso de ley" el que la ley posterior convalide con efectos retroactivos los efectos radicalmente nulos de un decreto-ley declarado por el Tribunal Constitucional nulo por extralimitación: "En efecto, lo que no puede en modo alguno hacer tal ley es ignorar el pronunciamiento constitucional que pueda haber hecho, en su caso, el propio Tribunal Constitucional. Ello es ilegítimo y constituye en nuestra opinión una utilización indebida de la posible retroactividad de las normas, pretendiendo que la situación no ha cambiado desde que se produjo el fallo constitucional, cuando lo cierto es que la realidad ha cambiado puesto que precisamente habría un fallo del propio Tribunal Constitucional", cuya labor devendría, precisamente por esta razón, inútil. Lo descrito es una referencia temprana en España a las leyes de sustitución o normas de convalidación que desgraciadamente proliferan para enervar la labor jurisdiccional y el mandato de que se cumpla lo juzgado.

10 Recientemente destacan las obras de Aragón Reyes (2016) y Hernández Ramos (2017).

11 Máxime teniendo en cuenta que las Cámaras representativas en España son muy dependientes del partido que sostenga en un momento dado al Gobierno y que la labor legislativa que emana de ellas corresponde en su mayor parte a los proyectos de ley que el Gobierno remite a las Cortes Generales. 


\section{DEL ORIGEN AL ABUSO DE ESTA FIGURA}

\section{Los requisitos del decreto-ley y la jurisprudencia constitucional que ha favorecido esta forma extraordinaria de legislar.}

Hay que advertir que, no por conocido huelga recordarlo, el empleo del decreto-ley es sin duda un medio legítimo a priori para la novación y reforma del ordenamiento jurídico cuando la premura y lo imprevisto, quizás también la imprevisión de la situación impide al Parlamento la aprobación de leyes ordinarias, ${ }_{12}^{12}$ por lo que hay que entender los motivos aducidos por el Gobierno para su elección, siempre que no se trate de las materias excluidas por la Constitución, en cuanto a la oportunidad técnica ${ }^{13}$ y política de apreciar la extraordinaria urgencia y necesidad, como reconoce la STC $\mathrm{n}^{0}$ 29/1982, de 31 de mayo, ${ }^{14}$ especialmente mediante la

12 Tribunal Constitucional Español, cuestiones de inconstitucionalidad acumuladas $n^{\circ} 19$ y 20 de 1982, Comunidades de Propietarios de los edificios $n^{\circ} 27$ y 37 de la avenida de España de dicha capital, en relación con la disposición transitoria segunda, letra b), del Real Decreto-ley de 20 de julio de 1979 (1983, sentencia n 6/1983), fundamento jurídico 5: “Por todo ello hay que concluir que la utilización Decreto-ley, mientras se respeten los límites del artículo 86 de la Constitución, tiene que reputarse como una utilización constitucionalmente lícita en todos aquellos casos en que hay que alcanzar los objetivos marcados para la gobernación del país, que, por circunstancias difíciles o imposibles de prever, requieren una acción normativa inmediata o en que las coyunturas económicas exigen una rápida respuesta".

13 La discrecionalidad técnica está a su vez limitada por la "fuerza normativa de los hechos", es decir, que ante cuestiones científicas y técnicas patentes, manifiestas e indubitadas, ni el Gobierno ni la Administración pueden negar ni su contenido ni sus efectos. Como dijo el maestro de juristas D. Eduardo García de Enterría: "No puede quedar al arbitrio de la Administración discernir si un hecho se ha cumplido o no se ha cumplido, o determinar que algo ha ocurrido si realmente no ha sido así. El milagro, podemos decir, no tiene cabida en el campo del Derecho Administrativo", a lo que se suma "el supuesto de hecho, en cuanto proviene directamente de la norma atributiva de la potestad, es siempre un elemento reglado del acto y, por tanto, perfectamente controlable por el juez", en este caso el magistrado constitucional. Vid. García De EnTerría y FERNÁNDEZ (1989) p. 537. Un ejemplo son los decretos-leyes sobre las sequías, cuya determinación, tipos y efectos son cuestiones científicas y de unos fenómenos propios y cíclicos de los diferentes climas en España, de ahí que se pueda afirmar que muchos solo son medios para eludir las leyes de contratos públicos y de evaluación de impacto ambiental porque incluyen obras cuyos períodos de ejecución sobrepasan con creces estos ciclos de sequía y desdeñan la aplicación de alternativas sobradamente demostradas. BrufAO CURIEL (2012). Sobre el control jurisdiccional de la discrecionalidad administrativa, vid. Desdentado Daroca (1997).

14 Fundamento jurídico 3: "Nuestra Constitución limita en un doble sentido la facultad excepcional que atribuye al Gobierno para promulgar, en forma de Decreto-Ley, normas con fuerza 
comparación con el período de tiempo previsible ante la aprobación de una ley por el procedimiento parlamentario de urgencia. ${ }^{15}$

\section{Sin embargo y no en pocas ocasiones como podremos observar, desde su incorporación al ordenamiento positivo español en la época del gobierno de Primo de Rivera ${ }^{16}$ durante el reinado de Alfonso XIII, sin que anterior- mente tuviera apoyo constitucional, la figura del decreto-ley se ha enten- dido y empleado como un modo alternativo de legislar en manos del poder ejecutivo y no una fuente del Derecho a la que se pueda acudir en supues- tos excepcionales y bajo el criterio de su aplicación restrictiva que lleven a un cierto equilibrio entre la aplicación por razones de necesidad y la merma en el poder reservado al legislativo. ${ }^{17}$ En efecto, la STC $n^{0} 6 / 1983$,}

de Ley. Esta limitación viene dada, de una parte, y como ha quedado dicho, por la exclusión de determinadas materias (ordenamiento de las instituciones básicas del Estado, derechos y libertades de los ciudadanos reguladas en el Título I, etc...) que en ningún caso pueden ser objeto de regulación mediante Decreto-Ley; de la otra, por la conexión establecida entre esta facultad legislativa excepcional y la existencia de un presupuesto habilitante concreto: el caso de extraordinaria y urgente necesidad. El aseguramiento de estos límites, la garantía de que en el ejercicio de esta facultad, como de cualquier otra, los poderes públicos se mueven dentro del marco trazado por la Constitución es, evidentemente, función propia de este T. C. (...). El peso que en la apreciación de lo que haya de considerarse como caso de extraordinaria y urgente necesidad es forzoso conceder al juicio puramente político de los órganos a los que incumbe la dirección política del Estado, no puede ser obstáculo para extender también el examen sobre la competencia habilitante al conocimiento del T. C., en cuanto sea necesario para garantizar un uso del Decreto-Ley adecuado a la Constitución. El T.C. podrá, en supuestos de uso abusivo o arbitrario, rechazar la definición que los órganos políticos hagan de una situación determinada como caso de extraordinaria y urgente necesidad, de tal naturaleza que no pueda ser atendida por la vía del procedimiento legislativo de urgencia. Es claro que el ejercicio de esta potestad de control del Tribunal implica que dicha definición sea explícita y razonada y que exista una conexión de sentido entre la situación definida y las medidas que en el Decreto-Ley se adoptan".

15 Artículos 93 y 94 del Reglamento del Congreso de los Diputados, por los que los plazos de la tramitación ordinaria se reducen a la mitad. Artículo 133 del Reglamento del Senado, que otorga un plazo de veinte días.

16 Mediante el Real Decreto de 15 de septiembre de 1923. Esta práctica disconforme con la naturaleza y funciones del decreto-ley tampoco desapareció durante la etapa de la II República, de 1931 a 1939, cuestión que tampoco desaprovechó el régimen franquista, el cual la incorporó mediante la Ley de Cortes de 1942 en los casos "de guerra o por razones de urgencia": MuÑoz (2006) p. 637.

17 Citamos nuevamente estas cuestiones de inconstitucionalidad acumuladas, $\mathrm{n}^{\circ} 19$ y 20 de 1982 , Tribunal Constitucional Español, Comunidades de Propietarios de los edificios $n^{o} 27$ y 37 de la avenida de España de dicha capital, en relación con la disposición transitoria segunda, letra b), del Real Decreto-ley de 20 de julio de 1979 (1983, sentencia $n^{\circ}$ 6/1983), sobre medidas urgentes de financiación de las Haciendas locales, norma que redujo la bonificación en la contribución 
recoge lo siguiente en un sorprendente giro interpretativo a favor de las tesis gubernamentales y en contra de la rigidez anterior: "Nuestra Constitución ha adoptado una solución flexible y matizada respecto del fenómeno del Decreto-ley, que, por una parte, no lleva a su completa proscripción en aras del mantenimiento de una rígida separación de los poderes, ni se limita a permitirlo en forma totalmente excepcional en situaciones de necesidad absoluta, entendiendo por tales aquellas en que puede existir un peligro inminente para el orden constitucional. Nuestra Constitución ha contemplado el Decreto-ley como un instrumento normativo, del que es posible hacer uso para dar respuesta a las perspectivas cambiantes de la vida actual, siempre que su utilización se realice bajo ciertas cautelas. Lo primero quiere decir que la necesidad justificadora de los Decretos-leyes no se puede entender como una necesidad absoluta que suponga un peligro grave para el sistema constitucional o para el orden público entendido como normal ejercicio de los derechos fundamentales y libertades públicas y normal funcionamiento de los servicios públicos, sino que hay que entenderlo con mayor amplitud como necesidad relativa respecto de situaciones concretas de los objetivos gubernamentales, que, por razones difíciles de prever, requieren una acción normativa inmediata en un plazo más breve que el requerido por la vía normal o por el procedimiento de urgencia para la tramitación parlamentaria de las leyes".18

Aquellas "perspectivas cambiantes de la vida actual" que consideró el Tribunal Constitucional se basaban en que "era absolutamente necesario asegurar el funcionamiento de las corporaciones locales democráticas elegidas en el mes de abril del año 1979 proveyéndolas de los recursos financieros necesarios para el desarrollo de sus funciones y la medida era todavía más necesaria si se tiene en cuenta que por imperio de la Constitución tales entidades habían devenido autónomas". ${ }^{19}$ Esto es, se deja en

tributaria urbana del 90 por ciento durante 20 años al 50 por ciento durante 13 años y cuya liquidación en un supuesto concreto es la causa de esta sentencia ya que, en opinión del propietario afectado, se quebrantaban los principios de legalidad, de respeto de los derechos individuales adquiridos, de seguridad jurídica y de interdicción de la arbitrariedad de los poderes públicos, consagrados en el párrafo $3^{\circ}$ del artículo 9 de la Constitución, así como los artículos 33 y 86, al privar de un derecho sin causa de utilidad pública o interés social y sin que medie indemnización y al afectar a materias relativas a derechos de ciudadanos regulados en el Título I de la Constitución.

18 Fundamento jurídico 5.

19 Máxime en la crisis económica de 1979, que arrastraba las consecuencias de la de 1973, así como la incertidumbre propia de la Transición. La financiación de las entidades locales sigue 
manos del Gobierno hacer uso de la discrecionalidad administrativa para colmar el contenido de los conceptos jurídicos indeterminados ${ }^{20}$ de la extraordinaria urgencia y necesidad, a lo que hay que sumar las también discutidas potestades de los órganos jurisdiccionales a la hora de apreciar que concurren aquellas circunstancias habilitantes y su capacidad de sustitución por una decisión judicial. Una flexibilidad del Tribunal Constitucional ante los límites jurídicos de esta fuente del Derecho extraordinaria que ha sido objeto de crítica en numerosas ocasiones y que puede incluso constituir un ejemplo de la figura conocida como "mutación constitucional", por la cual los términos de la Constitución adquieren un significado diferente del previsto por el constituyente debido principalmente a ciertas prácticas políticas gubernamentales y el dilema entre la constitución rígida frente a la flexible. ${ }^{21}$

La crítica, que comparto, sobre atender a las circunstancias cambiantes de la vida actual se acentúa cuando observamos la aprobación de los llamados decretos-leyes "ómnibus" sobre todo con motivo de la década larga de crisis económica que sufrimos, ${ }^{22}$ es decir, aquellos que regulan no ya una cuestión concreta o al menos varias diferentes pero conexas, sino aquellos que tratan materias imposibles de ligar incluso con la más benévola de las actitudes. El contenido heterogéneo de estos tipos de normas se aprovecha a su vez como incentivo a su aprobación dado el sistema de convalidación o de derogación, que se lleva a cabo mediante una votación de totalidad, que impide sopesar, medir y discriminar entre las variables y distintas materias que puede contemplar. ${ }^{23} \mathrm{~A}$ pesar de todos los

siendo, hoy en día, uno de los grandes asuntos pendientes de la Administración española, máxime teniendo en cuenta la gran dispersión de municipios, su baja y envejecida población y la asunción de competencias asistenciales, educativas y ambientales que en principio no les corresponderían, llamadas "competencias impropias". El problema de la legislación urgente sobre las haciendas locales se ha visto de nuevo regulada por el Real Decreto-Ley $\mathrm{n}^{0} \mathrm{1} / \mathbf{2 0 1 8}$, por el que se prorroga para 2018 el destino del superávit de las corporaciones locales para inversiones financieramente sostenibles y se modifica el ámbito objetivo de éstas.

20 Recomiendo la lectura de la obra ya clásica sobre la materia: Sáınz Moreno (1976).

21 Figura teorizada principalmente por Jellinek en su ya obra clásica: JELLINEK (1991). Más recientemente: Goig Martínez (2013). Desde un punto de vista muy crítico con la labor del Tribunal Constitucional respecto de los decretos-leyes, vid. Alegre Martínez (2017).

22 aragón Reyes (2016) pp. 101 y ss. Hernández Ramos (2017) p. 128. Y una crisis que sobrepasa una larga década será una situación grave, pero no tan urgente como para eludir la labor parlamentaria ordinaria.

23 Por ejemplo, el Real Decreto-ley no 8/2014, de aprobación de medidas urgentes para el crecimiento, la competitividad y la eficiencia, por mor del consabido argumento de la crisis eco- 
problemas que este tipo de normas provocan en la necesaria seguridad jurídica, en las garantías de los derechos y libertades y en el sistema institucional básico, la STC $n^{\circ}$ 199/2015, de 24 de septiembre, reconoce la singularidad de este tipo de normas y su carácter expansivo, pero le aplica el mismo tratamiento que el dado a las igualmente heterogéneas leyes de acompañamiento a las leyes de presupuestos generales del Estado, a pesar de los defectos de la técnica legislativa empleada. El nihil obstat del Tribunal Constitucional se expresa en su fundamento jurídico tercero: "el Tribunal ha profundizado en la cuestión planteada, avanzando en la idea de que las leyes ómnibus o leyes transversales (STC $n^{0}{ }_{132 / 2013}$, de 5 de junio, FJ 1), no son, por el mero hecho de su compleja estructura interna, lesivas de precepto constitucional alguno. (...) Pues bien, vista la doctrina expuesta, este Tribunal no encuentra objeción alguna para aplicarla a la hora de resolver la impugnación de un «decreto-ley ómnibus», partiendo, como hacíamos en aquellos pronunciamientos, del reconocimiento de que, si bien el Decreto-ley impugnado puede ser expresión de una deficiente técnica normativa, en este caso desarrollada por el Gobierno en ejercicio de las potestades legislativas que le concede la Constitución en el artículo $86 \mathrm{CE}$, hemos de limitarnos a realizar un juicio de constitucionalidad sobre la norma, porque no nos compete efectuar un control sobre su calidad técnica, del mismo modo que hemos afirmado, que no poseemos tal facultad en relación con el análisis de la perfección técnica de las leyes".

Este criterio formalista del Tribunal Constitucional y muy respetuoso con la actividad gubernamental fue duramente criticado por un contundente voto particular, ${ }^{24}$ por cuyo interés exponemos en parte y por cuya elocuencia sobran los comentarios: "Por más flexible que haya podido ser el canon hasta ahora aplicado por este Tribunal, como demuestra la experiencia, el solo recuento que somera y fragmentariamente ha quedado expuesto deja en evidencia que esta norma ha roto los diques constitu-

nómica como se recoge en su exposición de motivos, deroga siete normas con rango de ley o reglamentarias, modifica 22 normas más, prorroga la entrada en vigor de una ley y transpone parcialmente una directiva de la Unión Europea, afectando a una cincuentena de materias. Su contenido es tan heterogéneo que incluye normas sobre hidrocarburos, subvenciones al autoempleo, la consolidación de finanzas públicas, navegación aérea, defensa de la competencia, daños por terremotos, puertos marítimos, horarios comerciales, haciendas locales o yacimientos mineros, por citar algunas de las recogidas en sus 172 páginas.

De los Magistrados Asúa Batarrita, Valdés Dal-Ré y Xiol Ríos. 
cionales. Es palmario que no estamos ante un decreto-ley que responda a una situación de necesidad cuyo remedio exija medidas de contenido hasta cierto punto heterogéneo, pero que tengan un nexo común, consistente precisamente en esa situación de necesidad a la que pretenden salir al paso. Y es necesario subrayar que esta situación de necesidad no solo ha de quedar justificadamente caracterizada como urgente, en el sentido de que no pueda ser debidamente abordada ni siquiera a través de los cauces legislativos que otorgan carácter preferente o abrevian los plazos parlamentarios de tramitación legislativa. También es nota característica del presupuesto habilitante del artículo 86.1 CE el carácter extraordinario de la situación de necesidad, que es tanto como decir fuera de lo común, anómalo, difícil o imposible de prever. Cualquier intento de localizar en el Real Decreto-ley no 8/2014 este nexo común, esta situación de extraordinaria y urgente necesidad, resulta baldío por la sencilla razón de que no existe. Así lo revela la lectura del apartado I de su preámbulo, que prácticamente viene a otorgar carta de naturaleza al uso del decreto-ley como instrumento habitual y ordinario para impulsar una genérica agenda reformadora del Gobierno que, conectada con la recesión económica iniciada en 2008, pretende otorgar cobertura a la aprobación de tan amplio, disperso e inconexo conjunto de disposiciones. En el sentido constitucional del término, poco puede tener ya de extraordinaria una crisis económica que se extiende a lo largo de dos legislaturas, ni la crisis económica legitima el uso del decreto-ley para la aprobación de medidas de todo tipo, muchas de ellas ajenas a aquella".

Procediendo a estudiar el contenido material de los decretos-leyes, veremos cómo la jurisprudencia constitucional ha recaído tanto sobre los asuntos excluidos del ámbito material del decreto-ley como acerca de la exigencia de la extraordinaria urgencia y necesidad.

En cuanto a las materias excluidas del decreto-ley por "afectar" 25 al ordenamiento de las instituciones básicas del Estado, a los derechos, deberes y libertades de los ciudadanos del Título I de la Constitución,

25 Una crítica detallada a la afectación de las materias excluidas: ArAgón ReYES (2016) pp. 86 y ss. Este autor debate principalmente en este punto el que el TC no distinga entre la afectación el Derecho objetivo, regulador, de las materias excluidas y la afectación a los derechos y libertades fundamentales del Título I de la Constitución Española como derechos subjetivos, distinción ésta que los protege de un modo mayor frente a su regulación extraordinaria por decreto-ley. 
al régimen de las Comunidades Autónomas y al Derecho electoral general, ${ }^{26}$ la jurisprudencia constitucional estudia las particularidades de cada caso y el alcance del concepto esencial de cada una de aquellas materias, ya sea el sistema de distribución de competencias entre el Estado y las Comunidades Autónomas ${ }^{27}$ o el núcleo básico de las instituciones básicas del Estado, no de cualquier corporación de Derecho Público. ${ }^{28}$

26 Tribunal Constitucional Español, recurso previo de inconstitucionalidad $\mathrm{n}^{\circ}$ 132/1983, promovido por don José María Ruiz Gallardón, contra el texto definitivo del Proyecto de Ley Orgánica por la que se modifican determinados artículos de la Ley $n^{\circ} 39 / 1978$ (1983, sentencia ${ }^{\circ}$ 38/1983) y recurso previo de inconstitucionalidad no 863/1983, interpuesto por don Luis Fernández Fernández-Madrid y 52 Senadores más, contra el texto definitivo del Proyecto de Ley Orgánica de Incompatibilidades de Diputados y Senadores (1984, sentencia $\mathrm{n}^{0} 72 / 1984$ ), por las que queda extramuros del ámbito de un decreto-ley los elementos esenciales o regulatorios del sufragio, ya sea el activo o el pasivo, pero se afirma que el Gobierno sí puede regular de modo urgente y excepcional los aspectos organizativos y procedimentales de los comicios.

27 Tribunal Constitucional Español, recursos de inconstitucionalidad n ${ }^{\circ}$ 5014-2000, 5053-2000, 5056-2000 y n ${ }^{\circ}$ 5061- 2000 interpuestos por los Gobiernos de la Generalidad de Cataluña, del Principado de Asturias, de Aragón y de la Junta de Comunidades de Castilla-La Mancha, contra los artículos 7 y 8, y las disposiciones transitoria y final segunda del Real Decreto-ley $n^{\circ} 7 / 2000$, de 23 de junio, de medidas urgentes en el sector de las telecomunicaciones (2005, sentencia ${ }^{\circ}$ 332/2005), la cual distingue entre la proscrita delimitación competencial y la mera incidencia en las competencias autonómicas reguladas por decretos-leyes. Vid. Tribunal Constitucional Español, recurso de inconstitucionalidad $\mathrm{n}^{\circ}$ 71-2001, Consejo de Gobierno de la Comunidad Autónoma de Andalucía contra el artículo único, cardinales uno, dos y tres, del Real Decreto-ley $n^{o}$ 9/200o, de 6 de octubre, de modificación del Real Decreto Legislativo ${ }^{\circ}$ 1302/1986, de evaluación de impacto ambiental (2012, sentencia $\mathrm{n}^{\circ}$ 1/2012), que anula la disposición del Real Decreto-ley $n^{\circ}$ 9/200o, de modificación del Real Decreto legislativo $n^{\circ}$ 1302/1986, de evaluación de impacto ambiental porque remite a un futuro desarrollo reglamentario la regulación del procedimiento de evaluación ambiental de determinados proyectos, alterando el régimen de competencias. Este mismo razonamiento de un ulterior desarrollo reglamentario contemplado en un decreto-ley que altera el marco competencial territorial ha sido declarado inconstitucional según: Tribunal Constitucional Español, recurso de inconstitucionalidad $\mathrm{n}^{\circ}$ 4528-2012, Consejo de Gobierno de la Junta de Andalucía contra los artículos 2, 3, 4, 5, 6 Uno, Dos, Tres y Cuatro, 7 y Disposición Final Primera del Real Decreto-ley $n^{\circ}$ 14/2012 (2016, sentencia ${ }^{\circ}$ 26/2016), recaída sobre el Real Decreto-ley $n^{0}$ 14/2012.

28 En: Tribunal Constitucional Español, recurso de inconstitucionalidad $\mathrm{n}^{\circ} 101 / 1983$, interpuesto por don José María Ruiz Gallardón, comisionado por 54 Diputados, contra los artículos 1, 2, 3, apartados 1, 2, tercer párrafo, y 3; 4, 5, 6, apartado 2; 7, y Disposición final primera, apartado 1, del Real Decreto-ley $n^{\circ}$ 22/1982, de 7 de diciembre, sobre medidas urgentes de reforma administrativa (1986, sentencia no 6o/1986), fundamento jurídico 4, es muy explícita al respecto: “Si por «afectar» hubiera de entenderse cualquier forma de incidencia en el ordenamiento de las instituciones antes dichas y, en concreto, en el de la Administración del Estado, el Decreto-ley impugnado sería inconstitucional. No lo es, sin embargo, si se parte de la interpretación que del término «afectar» ha hecho, según: Tribunal Constitucional Español, recurso de inconstitucionalidad no 116/1983, promovido por José Ruiz Gallardón, contra Real Decreto-ley $n^{\circ} 2 / 1983$ sobre expropiación (1983, sentencia $n^{\circ}$ 111/1983), en la que, tras señalar que «la tesis partidaria 
Por ejemplo, la STC $\mathrm{n}^{\mathrm{o}}$ 108/2004, de 30 de junio, que resolvió el recurso contra un decreto-ley de medidas urgentes tributarias que llegó a modificar el tipo de gravamen, un elemento esencial de un impuesto, asumiendo la jurisprudencia anterior, declara que "es preciso recordar asimismo que, respecto de la interpretación de los límites materiales a la utilización del Decreto-ley, hemos venido manteniendo siempre una posición equilibrada que evite las concepciones extremas, de modo que «la cláusula restrictiva del artículo 86.1 de la Constitución ("no podrán afectar") debe ser entendida de modo tal que ni reduzca a la nada el Decreto-ley, que es un instrumento normativo previsto por la Constitución... ni permita que por Decreto-ley se regule el régimen general de los derechos, deberes y libertades del título I (...) Posición que nos ha llevado a concluir que el Decreto-ley «no puede alterar ni el régimen general ni los elementos esenciales del deber de contribuirs", pero no teniendo en cuenta un tributo concreto, sino bajo la consideración general de la carga tributaria para todos los ciudadanos y que depende de su patrimonio.

Esta posición "equilibrada" que ha de guardar el decreto-ley necesita contemplar las circunstancias propias de cada caso, como ya hemos anunciado. Así por ejemplo, la tipificación de infracciones y sanciones administrativas mediante esta figura y no una ley ordinaria, no vulnera el régimen jurídico de las materias excluidas, de acuerdo con la STC $n^{0} 3 / 1988$, de 21 de enero, sobre un decreto-ley de medidas de seguridad en establecimientos comerciales. La ratio decidendi se basaba en que nos encontramos ante una disposición con fuerza y valor de ley ya que la norma cuestionada no regulaba un régimen general de infracciones y sanciones, sino tan solo unos supuestos concretos, permaneciendo incólumes los rasgos constitucionales principales del Derecho administrativo sancionador. En cambio, en otra sentencia se ha afirmado que la posición central del Derecho al juez natural predeterminado por la Ley evita que su concreción se pueda

de una expansión de la limitación contenida en el artículo 86.1 de la Constitución se sustenta en una idea tan restrictiva del Decreto-ley que lleva en su seno el vaciamiento de la figura y la hace inservible para regular con mayor o menor incidencia cualquier aspecto concerniente a las materias incluidas en el Título I de la Constitución, sin más base interpretativa que el otorgamiento al verbo "afectar" de un contenido literal amplísimo» que "conduce a la inutilidad del Decreto-ley», se declara que "la cláusula restrictiva del artículo 86.1 de la Constitución Española ("no podrá afectar...") debe ser entendida de modo tal que ni reduzca a la nada el Decreto-ley... ni permita que por Decreto-ley se regule el régimen general de los derechos, deberes y libertades del título I, ni dé pie para que por Decreto-ley se vaya en contra del contenido o elementos esenciales de alguno de tales derechos». 
regular bajo decreto-ley, que no puede solo "afectar" sino que niega así la existencia de tal derecho fundamental a la tutela judicial efectiva. ${ }^{29}$

No sin una amplia polémica, la STC $n^{0}$ 111/1983, de 2 de diciembre, recaída sobre la expropiación singular de un importante grupo empresarial español, RUMASA, sirve para comprender la regulación del derecho de propiedad y su contrario de la expropiación forzosa, institución que se recoge y garantiza en el artículo 33 de la Constitución de 1978. De modo resumido, el TC se atiene a la excepcionalidad de la situación económica aducida por el Gobierno de la Nación a la hora de acordar la expropiación de esta empresa en relación con la estabilidad del sistema financiero y los posibles perjuicios a ahorradores y trabajadores, alterando el régimen ordinario de adopción del acuerdo de necesidad de ocupación de los bienes a expropiar, y también el orden del pago previo del justiprecio o la misma urgencia de dicha ocupación. En palabras del fundamento jurídico noveno de esta STC: "Es justamente la indicada situación extraordinaria y urgente la que legitima la expropiación dentro de la exigencia de una norma habilitante para cumplir con el primero de los requisitos de la expropiación forzosa cual es la declaración de utilidad pública o interés social, no reservada necesariamente a Ley formal en el sistema del régimen general expropiatorio y, desde luego, no reservada a Ley formal en la Constitución".

Una vez llevado a cabo el análisis del ámbito objetivo o material del Real Decreto-Ley y su interpretación constitucional, acudimos a sus elementos cualitativos como norma excepcional, cuya interpretación entendemos que incorrecta o interesada por parte del poder ejecutivo ha conducido al recurso desmedido de esta norma.

Desde la primera sentencia constitucional sobre esta cuestión se ha dicho en repetidísimas ocasiones que el decreto-ley es una norma "excepcional" $y$, por ende, la interpretación del hecho habilitante y sus efectos, para distinguirlos del procedimiento ordinario de elaboración legislativa, han de interpretarse restrictivamente. Sin embargo, esta clara diferencia se

29 Tribunal Constitucional Español, cuestión de inconstitucionalidad n ${ }^{0}$ 213/85, planteada por la Audiencia Provincial de San Sebastián por delitos de injurias al Rey y desórdenes públicos, sobre el art. 1 del Real Decreto-ley $n^{\circ}$ 19/1979 (1988, sentencia $n^{\circ}$ 95/1988). 
ha visto borrada ${ }^{30}$ por la confusión entre el "supuesto excepcional" y la "norma excepcional". El primero hace referencia a los casos que permiten la declaración de los estados de alarma, excepción y sitio (artículo 116 de la $\mathrm{CE}$ ), que pueden llegar a poner en grave riesgo el propio sistema constitucional ${ }^{31}$ y cuya respuesta no se puede encauzar por los instrumentos de poder que el Estado tiene reservados en circunstancias normales; por el contrario, los supuestos del artículo 86 son de una envergadura menor tal que no puedan llegar a poner en peligro nuestro sistema constitucional, pero que requieren de una respuesta que no puede esperar a la resolución de los trámites ordinarios oportunos. La especialidad del decreto-ley radica simplemente en lo extraordinario de su proceso de aprobación, que no reside en el Parlamento, sino en el Gobierno, al que de suyo le corresponde la potestad reglamentaria. Valga el juego de palabras: "El decreto-ley, en consecuencia, no es una norma de excepción, sino una norma excepcional". ${ }^{32}$

Esta confusión, como podrá entenderse con facilidad, ha dado pie a una jurisprudencia constitucional que permite adaptarse a las "circunstancias cambiantes de la vida actual", como hemos visto, sin que sea muy estricta al analizar la excepcionalidad del supuesto de hecho habilitante, pues la respuesta a los cambios sociales, económicos, políticos o económicos de una sociedad en rápida y constante transformación puede venir dada, sin problemas, por el Parlamento ${ }^{33} \mathrm{o}$ incluso por medio del ejercicio de la potestad reglamentaria o hasta por medio de una resolución administrativa. Mucho nos tememos que el empleo del decreto-ley se hace o bien

30 Aragón Reyes (2016) p. 56.

31 De hecho solo se ha acudido a declarar desde la entrada en vigor de la Constitución Española, el estado de alarma una sola vez, con motivo de una huelga de controladores aéreos, que supuso su puesta bajo el control de la Fuerza Aérea. En estos casos, el Gobierno puede incluso actuar por decreto. Vid. Tribunal Constitucional Español, recurso de amparo no 4703-2012, Pedro María Gragera de Torres y 326 personas más contra el Auto de la Sección Séptima de la Sala de lo Contencioso-Administrativo del Tribunal Supremo, de 30 de mayo de 2011 y Real Decreto $n^{0}$ 1717/2010, de 17 de diciembre (2016, sentencia no 83/2016) y GARRIDO LóPEZ (2017).

32 Aragón Reyes (2016) p. 57. Muñoz Machado (2006) p. 638: “(...) los decretos-leyes son normas de excepción contempladas en la Constitución con un criterio notoriamente restrictivo. Aceptada por ella que puedan concurrir circunstancias en las que es preciso reconocer al Gobierno la capacidad para intervenir normativamente con tanta fuerza, se pone el énfasis en la limitación de dicha facultad, para que no se convierta en ordinaria ni pueda sustituir la función constitucional atribuida al Parlamento".

33 El cual en la mayor parte de la aprobación normativa no hace sino transponer el Derecho de la Unión Europea. 
para eludir la intervención parlamentaria o bien para elevar de rango una cuestión que sin problema podría regularse por un decreto del Gobierno ${ }^{34}$ o una orden ministerial, elevando así de rango la fuente del Derecho y limitando en un grado importantísimo, prácticamente anulando, la posibilidad al ciudadano o el interesado del recurso ante la jurisdicción contencioso-administrativa, máxime si se trata de una cuestión propia de un mero acto administrativo.

Si entendemos que el principal rasgo definidor del decreto-ley es la premura, la urgencia y lo extraordinario de la situación que se le plantea al Gobierno, el criterio que sirve para delimitar la oportunidad de la aprobación de una norma excepcional como esta radicaría en que el examen alternativo de los plazos previstos para su tramitación ordinaria en las Cortes Generales no pudiera satisfacer dichos criterios excepcionales, no, sin más, cualquier circunstancia cambiante de la sociedad actual. ${ }^{35} \mathrm{De}$ lo contrario, estaríamos convirtiendo lo normal en anormal y viceversa,

34 Consecuencia derivada de la inexistencia en nuestro sistema de fuentes de una reserva material de reglamento como sí existe, sin embargo, la reserva de ley para la regulación de ciertas materias. Por tanto, se puede regular por ley, ya sea ordinaria u orgánica o por decreto-ley (con las salvedades expuestas) cualquier asunto.

35 En: Tribunal Constitucional Español, recursos de inconstitucionalidad $\mathrm{n}^{\circ} 7848-2014, \mathrm{n}^{\circ} 7874-$ 2014 y n $^{\circ}$ 21-2015, acumulados, interpuestos por el Parlamento de Cataluña, el Gobierno de la Generalitat de Cataluña y más de cincuenta diputados del Grupo Parlamentario Socialista del Congreso en relación con el Real Decreto-ley $n^{\circ}$ 13/2014 (2017, sentencia $n^{\circ}$ 152/2017), rechaza, por el contrario el que por decreto-ley se modifique el régimen de una explotación de almacenamiento de gas en alta mar, la plataforma Castor, y se le abonen al concesionario más de 1.30o millones de euros de dinero público por el cese de la actividad, aduciendo que (fundamento jurídico sexto): "ni el eventual ahorro económico para el sistema gasista ni el hecho de que esta operación de crédito contra el mismo no se compute en términos de contabilidad nacional, representan auténticas razones de urgencia a los efectos del artículo 86.1 CE. Parafraseando lo que hemos dicho en recientes sentencias, tales como: Tribunal Constitucional Español, recurso de inconstitucionalidad $\mathrm{n}^{\circ}$ 6524-2014, Grupos Parlamentarios Socialista; IU, ICV-EUIA, CHA: La Izquierda Plural; y Unión, Progreso y Democracia, en relación con el artículo 2.1 del Real Decreto-ley $n^{\circ}$ 10/2014 (2016, sentencia n ${ }^{\circ}$ 126/2016), FJ 6, y Tribunal Constitucional Español, recurso de inconstitucionalidad $\mathrm{n}^{\mathrm{o}}$ 3925-2015, Grupo Parlamentario Socialista en el Congreso contra el art. 1.1 del Real Decreto-ley $n^{\circ} 7 / 2015$ (2016, sentencia ${ }^{0}$ 169/2016), FJ 2, en relación con la utilización del decreto-ley como instrumento de habilitación de créditos, entonces para la adquisición de equipamiento militar, el ahorro o ventaja económica que pueda derivarse de una terminada operación no es «argumento válido para justificar la situación de "extraordinaria y urgente necesidad" requerida en el artículo 86 CE, si no va acompañado de una justificación adicional» que explicite, podemos añadir ahora, las razones por las cuales la asignación del pago al sistema gasista ha de llevarse a cabo en unos términos y plazos tan perentorios como para excluir el recurso al procedimiento legislativo ordinario o de urgencia". 


\section{alterando pues las facultades de producción normativa prevista por la $\mathrm{CE},{ }^{36}$ gracias a una mutación constitucional tácita.}

36 Yasí lo recogen los votos particulares a varias sentencias del Tribunal Constitucional emitidos por la Magistrada Casas Bahamonde y por el Magistrado Gay Montalvo en: Tribunal Constitucional Español, recursos de inconstitucionalidad no 5014-2000, 5053-2000, 5056-2000 y $\mathrm{n}^{0}$ 5061- 2000 interpuestos por los Gobiernos de la Generalidad de Cataluña, del Principado de Asturias, de Aragón y de la Junta de Comunidades de Castilla-La Mancha, contra los artículos 7 y 8, y las disposiciones transitoria y final segunda del Real Decreto-ley $n^{\circ} 7 / 2000$, de 23 de junio, de medidas urgentes en el sector de las telecomunicaciones (2005, sentencia $\left.\mathrm{n}^{0} 332 / 2005\right)$, que reproducimos por su claridad e interés: "A mi juicio, la idea de principio debiera ser que únicamente es admisible la adopción de un decreto-ley si es inaplazable regular una materia reservada a la ley en un tiempo inferior al necesario para la aprobación de una ley formal por las Cortes Generales (...) La mayoría viene a identificar la necesidad de adoptar con urgencia una disposición normativa con la licitud constitucional de la adopción de un decreto-ley. Sin embargo, la 'extraordinaria y urgente necesidad' relevante a los efectos del artículo 86.1 CE es sólo la referida a la adopción de normas con rango o valor de ley, de manera que si a la urgencia acreditada de la adopción de una norma se provee suficientemente con la emisión de un decreto, es decir, si el Gobierno puede subvenir a la situación de urgencia con el ejercicio de facultades normativas propias, no es constitucionalmente lícito que se sirva de facultades de las que sólo puede disponer cuando la intervención normativa necesaria lo es sobre un terreno reservado al legislador. A ello no puede oponerse que la ley no conoce límites frente al reglamento, pues aquí no se trata de la ley ni del legislador, sino de una norma excepcionalmente equiparada a la ley y adoptada por quien no es el titular de la potestad legislativa, sino sólo de la reglamentaria, por más que en determinadas circunstancias, para cohonestar, justamente, el respeto debido a la reserva de ley con la necesidad de regular materia reservada en un plazo inferior al establecido para la elaboración de una ley formal, se le habilite para dictar normas que valen como leyes en la medida estrictamente necesaria. El Gobierno, en suma, no puede regular legislativamente cualquier materia y en cualquier circunstancia, sino sólo cuando sea inevitable. (...) En efecto, la necesidad de reconducir la jurisprudencia del Tribunal en esta materia hacia cauces estrictamente adecuados al fundamento constitucional de la legislación de urgencia es, además, tanto más necesaria cuanto dejar al arbitrio del Gobierno la decisión de regular con valor de ley una materia que admite la disciplina reglamentaria lleva aparejada la nada despreciable consecuencia de dejar asimismo a su arbitrio la decisión acerca del régimen de enjuiciamiento jurisdiccional posible de la norma adoptada, con los evidentes perjuicios que de ello pueden derivar para la defensa de los derechos de los particulares. Especialmente en un caso como el planteado en el presente proceso constitucional, en el que el artículo 8 del Decreto-ley enjuiciado ("Modificación del Real Decreto 1987/1985, de 24 de septiembre, sobre normas básicas de instalación y funcionamiento de las Estaciones de Inspección Técnica de Vehículos") regula materia que hasta entonces sólo había sido regulada por reglamento y que en lo sucesivo, por obra del propio Decreto-ley, también puede ser objeto de regulación por simple decreto gubernamental, por cuanto el citado precepto del Decreto-ley deslegaliza, en unidad de acto, la materia que empieza legalizando, que adquiere así el régimen jurisdiccional propio de las normas con rango legal, en perjuicio de la defensa de los derechos e intereses de los particulares ante la jurisdicción contencioso- administrativa". En el mismo sentido, vid. el voto particular del Magistrado Ortega Álvarez en: Tribunal Constitucional Español, recurso de inconstitucionalidad n ${ }^{\circ}$ 3931-2013, Grupo Parlamentario Socialista en relación con el Real Decreto-Leyn $n^{\circ}$ 6/2013 (2015, sentencia no 12/2015). 
Hemos de tratar a su vez el criterio de la provisionalidad del decreto-ley. Una interpretación somera de este criterio de la provisionalidad nos puede llevar a tres conclusiones. ${ }^{37}$

La primera atiende a su significado literal, pues "provisional" es según el Diccionario de la Real Academia Española aquello que "se hace, se halla o se tiene temporalmente". El carácter coyuntural del presupuesto de hecho habilitante es una de los caracteres esenciales de esta norma excepcional $y$, por lo tanto, rechazaría una interpretación estable pro futuro. ${ }^{38}$

La segunda interpretación es de base estrictamente jurídica: si esa provisionalidad se refiere a la extraordinaria urgencia de su aprobación y cuya vigencia resultará mientras no se produzca el acto convalidatorio o la derogación del decreto-ley. ${ }^{39}$ Como ha afirmado la STC $n^{0}$ 189/2005, de 7 de julio, asumiendo jurisprudencia anterior: "En efecto, como se ha recordado recientemente, "en la STC n ${ }^{0}$ 111/1983 (FJ 3) estableció nuestra jurisprudencia una conexión entre el carácter provisional del Decreto-ley (artículo 86.1 CE) y la necesidad de que sea convalidado o derogado en el plazo de treinta días por el Congreso de los Diputados (artículo 86.2 CE), de forma tal que, una vez que se ha producido esa convalidación, 'cede su carácter de provisionalidad' (STC n ${ }^{0}$ 178/2004 de 21 de octubre, FJ 6). Ningún dato positivo constitucional permite afirmar, en consecuencia, que el carácter provisional del Decreto-ley se refiera necesariamente al alcance temporal de la norma que con esa forma jurídica se apruebe, sin perjuicio de que dicho alcance pueda ser considerado de algún modo para valorar -ya en otro plano- la concurrencia del presupuesto de la extraordinaria y urgente necesidad de la medida legislativa".

37 Aragón Reyes (2016) p. 67.

38 De ahí que haya criticado el recurso al decreto-ley para abordar la aprobación de obras públicas cuyos plazos de ejecución puede demorarse incluso decenios. BrUfaO CURIEL (2012) p. 206. $\mathrm{O}$ como cuando se reforma el sistema tributario sine die no para hacer frente a un ejercicio anual para cuya tramitación parlamentaria ordinaria no diese tiempo, caso de: Tribunal Constitucional Español, Cuestión de inconstitucionalidad n ${ }^{\circ}$ 222/1982, promovida por la Sala Sexta del Tribunal Supremo, contra el artículo 170 del Real Decreto legislativo 1568/1980 (1983): 25 de enero de 1983, Sentencia n ${ }^{\circ} 3 / 1983$.

Aragón Reyes (2016) p. 69. 
Por último, la tercera interpretación es asimismo jurídica e incluye, por simple interpretación sistemática, el caso de que la provisionalidad persista hasta que no entre en vigor una ley que derogue el decreto-ley en cuestión, mutando esta regulación provisional en estable.

\section{Examen de la influencia de los decretos-leyes en el sistema de fuentes del Derecho español}

En esta sección mostraremos un análisis cuantitativo que demuestra el abuso relativo del empleo del decreto-ley en España, vistas ya las implicaciones jurídicas cualitativas y también de oportunidad de su publicación.

Como podrá observar el lector, el número de decretos-leyes nacionales publicados en España no es desdeñable y su porcentaje respecto de las otras fuentes del Derecho tampoco, un ejemplo más del carácter fuertemente presidencialista ${ }^{40}$ de nuestro sistema político en la práctica, apoyado a su vez en los pilares de un "Estado de partidos". ${ }^{41}$

En el siguiente cuadro ofrecemos una sencilla estadística sobre la publicación de normas con rango de ley a partir del año 2010, cuando la crisis económica ya ofrecía sus consecuencias más perjudiciales, obtenida de la web del Boletín Oficial del Estado: ${ }^{42}$

\begin{tabular}{|l|c|c|c|c|c|c|c|c|c|}
\hline & 2017 & 2016 & 2015 & 2014 & 2013 & 2012 & 2011 & 2010 & TOTAL \\
\hline Decreto-Ley & 21 & 7 & 12 & 17 & 17 & 29 & 20 & 14 & 137 \\
\hline Ley ordinaria & 12 & 0 & 48 & 36 & 27 & 17 & 38 & 44 & 222 \\
\hline Ley orgánica & 1 & 2 & 16 & 8 & 9 & 8 & 12 & 9 & 65 \\
\hline Decreto Legislativo & 0 & 1 & 8 & 0 & 1 & 0 & 3 & 1 & 14 \\
\hline TOTAL & 34 & 10 & 84 & 61 & 54 & 54 & 73 & 68 & 438 \\
\hline
\end{tabular}

40 Paniagua (2012) pp.225-268.

41 Me remito a la obra clásica del Presidente del Tribunal Constitucional español, según GARCía-Pelayo, (1986).

42 www.boe.es. En Hernández Ramos (2017) pp. 141-142 se ofrecen unos cuadros estadísticos en el período 2000-2015. Con un carácter más exhaustivo se ofrecen los datos desde el inicio de nuestra etapa democrática en ARAGón ReYES (2016) pp. 34 y ss. 
En cuanto a los porcentajes sobre el total de las normas con rango de ley publicadas tenemos los siguientes:

\begin{tabular}{|l|c|c|c|c|c|c|c|c|c|}
\hline & 2017 & 2016 & 2015 & 2014 & 2013 & 2012 & 2011 & 2010 & TOTAL \\
\hline Decreto-Ley & $61^{\prime} 7$ & 70 & $14^{\prime} 2$ & $27^{\prime} 8$ & $31^{\prime} 4$ & $53^{\prime} 7$ & $27^{\prime} 3$ & $20^{\prime} 5$ & $31^{\prime} 2$ \\
\hline
\end{tabular}

Un breve momento de atención sobre estas cifras nos permite vislumbrar el resultado de producción legislativa en el período 2010-2017, ${ }^{43}$ sobre todo en lo que respecta a la relación entre el decreto-ley y la ley ordinaria, con unos porcentajes nada desdeñables en cuanto a la justificación de una extraordinaria urgencia y necesidad.

Es muy indicativo el hecho de que a medida que mejoran los datos económicos con una lenta y paulatina salida de la crisis financiera y económica aumenta en un grado sumo el recurso al decreto-ley en los años 2016 y 2017 justo cuando en España resultaba muy difícil el mantenimiento del gobierno y era patente la parálisis gubernamental y parlamentaria resultados de unas elecciones que no dieron como saldo una mayoría holgada.

Es decir, que la extraordinaria y urgente necesidad se ha predicado no de la propia naturaleza de las cosas, sino de la falta de apoyos parlamentarios necesarios del Gobierno en las Cortes Generales y de la especial debilidad de un sistema parlamentario muy dependiente de la iniciativa del poder ejecutivo, que cuando cuenta con mayorías absolutas, el Parlamento hace de caja de resonancia de la voluntad gubernamental y cuando no es el caso, el Gobierno elabora normas con fuerza de ley de naturaleza eminentemente reglamentaria. Solo de esta manera podríamos entender la coincidencia no ya de la crisis económica, sino de los períodos electorales

43 A mediados de mayo de 2018 ya se habían publicado en este año 3 decretos-leyes, una ley ordinaria y ningún decreto-legislativo, mientras que solamente se ha promulgado una ley ordinaria, que apela directamente a circunstancias excepcionales: Ley $\mathrm{n}^{\circ} 1 / 2018$, por la que se adoptan medidas urgentes para paliar los efectos producidos por la sequía en determinadas cuencas hidrográficas y se modifica el texto refundido de la Ley de Aguas, aprobado por Real Decreto Legislativo $n^{0} 1 / 2001$, de 20 de julio. El primer Decreto Ley de 2018 se refería, como ya sabemos, a la prórroga de las medidas sobre el superávit de las corporaciones locales, el segundo a la incorporación de una Directiva de la Unión Europea sobre algo tan estable como las funciones de las entidades gestoras de derechos de propiedad intelectual y el tercero a algo tan perentorio tras discutirse en los últimos años como el arrendamiento de vehículos con conductor. 
en el devenir de la producción legislativa española, algo que no debería extrañarnos si realmente el poder ejecutivo adoptase los decretos-leyes con la debida proporción entre los fines buscados y los medios extraordinarios puestos en su mano, más allá de la mera razonabilidad o si acaso de la menos rigurosa ausencia de arbitrariedad, pues para eso disponemos del procedimiento urgente de aprobación de leyes ordinarias.

\section{CONCLUSIONES}

Por definición, lo extraordinario, lo urgente y lo necesario se da en un porcentaje relativo de situaciones. De lo contrario habríamos invertido el sentido normal y ordinario de los conceptos, viviendo "normalmente" en un estado excepcional independientemente de la coyuntura social, política o económica y de los ciclos que suelen acompañarles.

El dato de que las normas con fuerza de ley publicadas en España en un período de ocho años debida a situaciones formalmente aducidas como de necesidad extraordinaria y urgente superen un tercio del total, y en algunos años llegue al 6o y al 7o por ciento, nos debe hacer pensar que nos encontramos ante un claro e indubitado abuso de la figura del decreto-ley.

Las causas podrían identificarse en el propio sistema político, que hace que el Parlamento español sea políticamente muy dependiente de la voluntad del poder ejecutivo, así como en la carencia de la voluntad negociadora de los partidos con representación parlamentaria. A su vez, la doctrina del Tribunal Constitucional no ha hecho sino favorecer el empleo y el mismo abuso de los decretos-leyes con la estimación de las circunstancias cambiantes de la sociedad como justificante, o incluso como excusa, de la, esta vez sí, extraordinaria abundancia de una verdadera norma excepcional que podría calificarse como causante de una mutación constitucional.

Algunos autores han aludido a diversas reformas para reducir este uso injustificado. ${ }^{44}$ Una de ellas sería el que se siguiera la tramitación complementaria y

44 Sobre el conjunto de alternativas: Aragón Reyes (2016) pp. 174 y ss. Una de ellas, obviamente, es la reforma constitucional que elimine el decreto-ley como fuente del Derecho, opción que rechazo ya que, como resulta obvio, sí que existen circunstancias imprevisibles o inabarcables 
subsidiaria del decreto-ley como proyecto de ley en las Cortes generales (artículo 86.3 CE) dado que el Reglamento del Congreso de los Dipu$\operatorname{tados}^{45}$ estipula que haya de ser tramitado tras el acto de convalidación. De este modo, no se tendría que esperar al plazo previsto por la CE y se reducirían los alegados motivos de la urgencia para la promulgación del decreto-ley.

Otra vía alternativa a la jurisprudencia constitucional actual que se ha planteado es la de establecer una suerte de "reserva de reglamento"46 por la cual les estaría vedado al decreto-ley todo aquello que bien pudiera regularse por vía reglamentaria, es decir, todo aquello que no fuera objeto de reserva de ley, lo que a su vez garantizaría el acceso de los interesados a la jurisdicción contencioso-administrativa, dados los estrictos requisitos de la legitimación activa y los limitados motivos para recurrir leyes ordinarias ante el Tribunal Constitucional.

Junto a la interdicción de decretos-leyes heterogéneos, "ómnibus", por las razones expuestas más arriba, se precisa que su carácter provisional se predique durante toda la vida del decreto-ley, no hasta el momento de su convalidación. Es decir, que la provisionalidad englobe por completo este tipo de normas, pues de lo contrario hemos visto cómo se emplea el subterfugio de regular pro futuro y con ánimo de permanencia algo que debería ser temporalmente breve.

Por último, apoyo la tesis de que el decreto-ley debe incluir en su exposición de motivos una justificación, expresa clara y concisa de la delimitación del presupuesto de hecho habilitante ${ }^{47}$ tanto de la necesidad existente como de sus propiedades urgentes y extraordinarias, cuestiones que no ha de pasar el filtro de la jurisdicción constitucional de la "razonabilidad" o de ausencia de arbitrariedad o irrazonabilidad lógica, sino

con medios ordinarios que realmente sean de acometer por una necesidad extraordinaria y urgente.

45 Artículo 151. 4: "Convalidado un Real Decreto-ley, el Presidente preguntará si algún Grupo Parlamentario desea que se tramite como proyecto de ley. En caso afirmativo, la solicitud será sometida a decisión de la Cámara. Si ésta se pronunciase a favor, se tramitará como proyecto de ley por el procedimiento de urgencia, sin que sean admisibles las enmiendas de totalidad de devolución". 
el que realmente expone el artículo 86 de la CE: la potestad excepcional de legislar. Se trata, pues, de un juicio de proporcionalidad entre los fines perseguidos por una norma excepcional y los medios que se les ofrece al competente para dictarla, alterando el procedimiento ordinario y, por tanto, general de producción normativa. Es más, se propone la inversión de la carga de la prueba en el juicio constitucional: "Ya no se trataría de que el decreto-ley fuese inconstitucional sólo si el Tribunal constase la arbitrariedad en su emanación, sino que sería inconstitucional si el Gobierno, en la motivación del decreto-ley, no ha justificado suficientemente que cumple todos los requisitos que la Constitución exige para dictarlos", ${ }^{48}$ siempre de modo que no dé lugar a dudas o a incertidumbre y no bajo una interpretación relativa que someta a criterios muy laxos la adecuación de las medidas adoptadas al fin perseguido. ${ }^{49}$

48 Aragón Reyes (2016) pp. 196 y 197. En: Tribunal Constitucional Español, recursos de inconstitucionalidad, acumulados $\mathrm{n}^{\mathrm{o}}$ 4781-2002 y $\mathrm{n}^{\circ}$ 4915-2002 interpuestos, por el Consejo de Gobierno de la Junta de Andalucía y Procurador de los Tribunales don Roberto Granizo Palomeque (2007, sentencia $n^{0}$ 68/2007), resuelve el recurso contra el Real Decreto-ley ${ }^{\circ} 5 / 2002$, de medidas urgentes para la reforma del sistema de protección por el desempleo y mejora de la ocupabilidad, publicado no con ocasión de la crisis, sino cuando la economía española se encontraba en plena expansión y creación de empleo. Este decreto-ley, en suma, eliminaba bajo ciertas condiciones los llamados salarios de tramitación devengados entre el despido de un trabajador y la publicación de la sentencia del orden social sobre tal despido. El fundamento jurídico 12 de esta sentencia estableció que "el Gobierno no ha aportado ninguna justificación que permita apreciar la existencia de la situación habilitante requerida por el artículo 86.1 CE. Los argumentos que al respecto se utilizan en el preámbulo del Real Decreto-ley no sólo resultan marcadamente teóricos y abstractos, impidiendo con ello todo control de contraste con la realidad, sino que, en buena medida, han sido matizados -cuando no neutralizados- por la propia percepción de la realidad transmitida por el Gobierno en el debate parlamentario de convalidación. Y, en todo caso, en ningún momento se ha justificado cuáles serían los perjuicios u obstáculos que, para la consecución de los objetivos perseguidos, se seguirían de su tramitación por el procedimiento legislativo parlamentario, en su caso por el trámite de urgencia". En: Tribunal Constitucional Español, recursos de inconstitucionalidad, acumulados $n^{\circ} 4781$ 2002 y n ${ }^{\circ}$ 4915-2002 interpuestos, por el Consejo de Gobierno de la Junta de Andalucía y Procurador de los Tribunales don Roberto Granizo Palomeque (2007, sentencia n ${ }^{\circ} 68 / 2007$ ), se resuelve el recurso contra el Real Decreto-ley ${ }^{0} 5 / 2002$, de medidas urgentes para la reforma del sistema de protección por el desempleo y mejora de la ocupabilidad. Este decreto-ley, en suma, eliminaba bajo ciertas condiciones los llamados salarios de tramitación devengados entre el despido de un trabajadory la publicación de la sentencia del orden social sobre tal despido. El fundamento jurídico 12 de esta sentencia estableció que "el Gobierno no ha aportado ninguna justificación que permita apreciar la existencia de la situación habilitante requerida por el artículo 86.1 CE. Los argumentos que al respecto se utilizan en el preámbulo del Real Decreto-ley no sólo resultan marcadamente teóricos y abstractos, impidiendo con ello todo control de contraste con la realidad, sino que, en buena medida, han sido matizados - cuando no neutralizados- por la propia percepción de la realidad transmitida por el Gobierno en el debate 


\section{BIBLIOGRAFÍA CITADA}

Alegre Martínez, Miguel (2017): "Vigilando al vigilante: El Tribunal Constitucional y sus circunstancias", Revista Jurídica de la Universidad de León, $\mathrm{n}^{\mathrm{o}}$ 4, pp. 135-164. Disponible en: http://revpubli.unileon.es/index.php/ juridica/article/download/5289/4112, fecha de consulta: 5 mayo 2017

Álvarez García, Vicente (1996): El estado de necesidad en Derecho público (Madrid, Civitas).

Aragón ReYes, Manuel (2016): Uso y abuso del decreto-ley. Una propuesta de reinterpretación constitucional (Madrid, lustel).

Brufao Curiel, Pedro (2012): “El régimen jurídico de las sequías. Crítica a la regulación extraordinaria y urgente de un fenómeno y natural cíclico y propio del clima", Revista de Administración Pública, $\mathrm{n}^{0} 187$, pp. 199-239. Disponible en: http://www.cepc.gob.es/Controls/Mav/ getData.ashx?MAVqs= aWQ9NjEmaWRIPTEwMzcmdXJsPTAmbmFtZT1QZWRyb19CcnVmYW9fQ3VyaWVsX1JBUDE4Ny5wZGYmZmlsZToxOTcoMzE3OTQzMzQucGRmJnRhYmxhPUFydGljdWxvJmNvbnRlbnQ9YXBwbGljYXRpb24vcGRm, fecha de consulta: 7 junio 2017.

Desdentado Daroca, Eva (1997): Los problemas del control judicial de la discrecionalidad técnica. Un estudio crítico de la jurisprudencia (Madrid, Civitas).

García De Enterría, Eduardo y Fernández, Tomás Ramón (1989): Curso de Derecho Administrativo I ( 5 a edición, Madrid, Civitas).

García De Enterría, Eduardo y Fernández, Tomás Ramón (2002): Curso de Derecho Administrativo I ( $11^{\text {a }}$ edición, Madrid, Civitas).

parlamentario de convalidación. Y, en todo caso, en ningún momento se ha justificado cuáles serían los perjuicios u obstáculos que, para la consecución de los objetivos perseguidos, se seguirían de su tramitación por el procedimiento legislativo parlamentario, en su caso por el trámite de urgencia". 
García-Pelayo, Manuel (1986): El Estado de partidos (Madrid, Alianza Editorial).

Garrido López, Carlos (2017): "Naturaleza jurídica y control jurisdiccional de las decisiones constitucionales de excepción", Revista Española de Derecho Constitucional, $\mathrm{n}^{0}$ 110, pp. 43-73. Disponible en: http://www.cepc.gob.es/Controls/Mav/getData.ashx?MAVqs= aWQ9MzgxNDUmaWRIPTEwMzcmdXJsPTc2Jm5hbWUgUkVEQzExMF8wMlgDYXJsb3 NfR2Fycmlkb19Mb33lei5wZGYmZmlsZTozNjU4MTg1MzQ3OTgucGRmJnRhYmxhPUFydGljdWxvJmNvbnRlbnQ9YXBwbGljYXRpb24vcGRm, fecha de consulta: 20 mayo 2017.

GoIG MARTíneZ, Juan (2013): “La interpretación constitucional y las sentencias del Tribunal Constitucional. De la interpretación evolutiva a la mutación constitucional", Revista de Derecho UNED, nº 12, pp. 257-292. Disponible en: http://e-spacio.uned.es/fez/eserv/bibliuned:RDUNED-2013-12-6035/Documento.pdf, fecha de consulta: 4 marzo 2017.

González García, Ignacio (2017): "La trascendencia constitucional del deficiente control del decreto ley autonómico", Revista Española de Derecho Constitucional, $\mathrm{n}^{\circ}$ 111, pp. 99-124. Disponible en: https://recyt.fecyt.es/ index.php/REDCons/article/download/62143/37993, fecha de consulta: 15 julio 2017.

HeRnández Ramos, Mario (2017): "La respuesta del Tribunal Constitucional a los Decretos-Leyes en materia de derechos sociales. El criticable retroceso de la jurisprudencia constitucional", Revista Vasca de Administración Pública, $\mathrm{n}^{\mathrm{O}}$ 109-II, pp. 119-143. Disponible en: https://apps. euskadi.eus/t59auUdaWar/R2/getPidFile/og029670803bf6ac?fileName=06\%2ORVAP\%2O109-II\%2ODIG\%2Epdf\&Ro1HNoPortal=true, fecha de consulta: 23 mayo 2017.

JeLLINEK, Georg (1991): Reforma y mutación de la Constitución (Madrid, Centro de Estudios Constitucionales).

Muñoz Machado, Santiago (2006): Tratado de Derecho Administrativo y Derecho Público General, vol. II (Madrid, lustel). 
PANIAgua, Juan (2012): "España: Un parlamentarismo racionalizado de corte presidencial", en LANZARO, Jorge (ed.): Presidencialismo y parlamentarismo. América Latina y Europa meridional. Argentina, Brasil, Chile, España, Italia, México, Portugaly Uruguay (Madrid, Centro de Estudios Constitucionales) pp. 225-268.

Sainz Moreno, Fernando (1976): Conceptos jurídicos, interpretación y discrecionalidad administrativa (Madrid, Civitas).

Soriano García, José (1983): "Los decretos-leyes en la jurisprudencia constitucional española", Revista de Administración Pública, $\mathrm{n}^{\circ}$ 100102: pp. 453-470. Disponible en: http://www.cepc.gob.es/Controls/ Mav/getData.ashx?MAVqs= aWQgMjMzNTMmaWRIPTEwMzcmdXJsPTEmbmFtZToxOTgzXzEwMCoxMDJfNDUzLIBERiZmaWxIPTE5ODNfMTAwLTEwMl8oNTMuUERGJnRhYmxhPUFydGljdWxvJmNvbnRIbnQ9YXBwbGljYXRpb24vcGRm, fecha de consulta: 2 agosto 2017.

\section{NORMAS JURÍDICAS CITADAS}

Constitución Española de 1978.

Constitución de la República de Chile, del 24 de octubre de 1980.

Reglamento del Congreso de los Diputados de España.

Reglamento del Senado de España.

Ley $\mathrm{n}^{\circ} 1 / 2018$, del 6 de marzo de 2018, por la que se adoptan medidas urgentes para paliar los efectos producidos por la sequía en determinadas cuencas hidrográficas.

Real Decreto-ley ${ }^{\circ}$ 11/1979, del 20 de julio de 1979, sobre medidas urgentes de financiación de las Haciendas locales.

Real Decreto-ley $n^{\circ}$ 9/2000, del 28 de junio de 2000, de modificación del Real Decreto legislativo ${ }^{\circ}$ 1302/1986, de evaluación de impacto ambiental. 
Real Decreto-ley ${ }^{\circ} 5 / 2002$, del 24 de mayo de 2002, de medidas urgentes para la reforma del sistema de protección por el desempleo y mejora de la ocupabilidad.

Real Decreto-ley $\mathrm{n}^{\circ}$ 14/2012, del 20 de abril de 2012, de medidas urgentes de racionalización del gasto público en el ámbito educativo.

Real Decreto-ley n 8/2014, del 4 de julio de 2014, de aprobación de medidas urgentes para el crecimiento, la competitividad y la eficiencia.

Real Decreto-Ley $\mathrm{n}^{\circ} \mathbf{1} / 2018$, de 23 de marzo de 2018 , por el que se prorroga para 2018 el destino del superávit de las corporaciones locales para inversiones financieramente sostenibles y se modifica el ámbito objetivo de éstas.

\section{JURISPRUDENCIA CITADA}

Tribunal Constitucional Español, recurso de inconstitucionalidad, promovido por cincuenta y cuatro Diputados contra el Real Decreto-Ley $n^{o}$ 10/1981, sobre Inspección y Recaudación de la Seguridad Social (1981): 31 de mayo de 1982, sentencia ${ }^{\circ}$ 29/1982, ECLI:ES:TC:1982:29.

Tribunal Constitucional Español, cuestión de inconstitucionalidad $\mathrm{n}^{0}$ 222/1982, promovida por la Sala Sexta del Tribunal Supremo, contra el artículo 170 del Real Decreto legislativo ${ }^{0}$ 1568/1980 (1983): 25 de enero de 1983, sentencia $n^{0} 3 / 1983$.

Tribunal Constitucional Español, cuestiones de inconstitucionalidad acumuladas $\mathrm{n}^{\circ} 19$ y 20 de 1982, Comunidades de Propietarios de los edificios $n^{\circ} 27$ y 37 de la avenida de España de dicha capital, en relación con la disposición transitoria segunda, letra b), del Real Decreto-ley de 20 de julio de 1979 (1983): 4 de febrero de 1983, sentencia n 6/1983, ECLI:ES:TC:1983:6.

Tribunal Constitucional Español, recurso previo de inconstitucionalidad $\mathrm{n}^{\mathrm{0}}$ 132/1983, promovido por don José María Ruiz Gallardón, contra el texto definitivo del Proyecto de Ley Orgánica por la que se modifican determinados arts. de la Ley $n^{\circ}$ 39/1978 (1983): 16 de mayo de 1983, sentencia 
$n^{\circ} 38 / 1983$, ECLI:ES:TC:1983:38.

Tribunal Constitucional Español, recurso de inconstitucionalidad $\mathrm{n}^{\mathrm{o}}$ 116/1983, promovido por José Ruiz Gallardón, contra Real Decreto-ley $n^{o}$ 2/1983 sobre expropiación (1983): 2 de diciembre de 1983, sentencia $\mathrm{n}^{\mathrm{o}}$ 111/1983, ECLI:ES:TC:1983:111.

Tribunal Constitucional Español, recurso previo de inconstitucionalidad no 863/1983, interpuesto por don Luis Fernández Fernández-Madrid y 52 Senadores más, contra el texto definitivo del Proyecto de Ley Orgánica de Incompatibilidades de Diputados y Senadores (1984): 14 de junio de 1984, sentencia $\mathrm{n}^{0}$ 72/1984, ECLI:ES:TC:1984:72.

Tribunal Constitucional Español, recurso de inconstitucionalidad $\mathrm{n}^{\mathrm{o}}$ 101/1983, interpuesto por don José María Ruiz Gallardón, comisionado por 54 Diputados, contra los arts. 1, 2, 3, apartados 1, 2, tercer párrafo, y 3; 4, 5, 6, apartado 2; 7, y Disposición final primera, apartado 1, del Real Decreto-ley $n^{0}$ 22/1982, de 7 de diciembre, sobre medidas urgentes de reforma administrativa (1986): 20 de mayo de 1986, sentencia $\mathrm{n}^{\circ}$ 6o/1986, ECLI:ES:TC:1986:60.

Tribunal Constitucional Español, cuestiones de inconstitucionalidad acumuladas n $n^{\circ}$ 926/1984 y n ${ }^{\circ}$ 237/1986, interpuestos por don Damián Olcina López y el Banco Central, contra Acuerdos del Gobierno Civil de Valencia que imponía sanciones de multa por incumplimiento de medidas de seguridad en establecimientos comerciales, en aplicación de lo previsto en el art. 9 del Real Decreto-ley $n^{\circ}$ 3/1979, de 26 de enero (1988): 21 de enero de 1988, sentencia ${ }^{0}$ 3/1988, ECLI:ES:TC:1988:3.

Tribunal Constitucional Español, cuestión de inconstitucionalidad $\mathrm{n}^{\mathrm{o}}$ 213/85, planteada por la Audiencia Provincial de San Sebastián por delitos de injurias al Rey y desórdenes públicos, sobre el art. 1 del Real Decreto-ley $n^{0}$ 19/1979 (1988): 26 de mayo de 1988, sentencia $n^{0}$ 95/1988, ECLI:ES:TC:1988:93.

Tribunal Constitucional Español, recursos de inconstitucionalidad acumulados $\mathrm{n}^{0} 2.548 / 92$ y $\mathrm{n}^{0}$ 553/93, promovidos por Federico Trillo-Figueroa Martínez-Conde, contra los arts. 2 y 6.1 del Real Decreto-ley $n^{o}$ 5/1992, de 21 de julio, de Medidas Presupuestarias Urgentes y art. 2 de la 
Ley $n^{\circ}$ 28/1992 (1987): 28 de octubre de 1997, sentencia $n^{0}$ 182/1997, ECLI:ES:TC:1997:182.

Tribunal Constitucional Español, recurso de inconstitucionalidad $\mathrm{n}^{0}$ 3907/96, promovido por el Gobierno de Canarias contra el art. 8, apartados 1, 3 a) y 4, del Real Decreto-ley $n^{0}$ 12/1996, de 26 de julio, por el que se conceden créditos extraordinarios para atender obligaciones de ejercicios anteriores y regularizar anticipos de fondos y medidas tributarias urgentes (2004): 30 de junio de 2004, sentencia $\mathrm{n}^{\circ}$ 108/2004, ECLI:ES:TC:2004:108.

Tribunal Constitucional Español, cuestiones de inconstitucionalidad acumuladas $n^{0}$ 4104/99 y 1661-2002, en relación con el art. 11 de la Ley del Parlamento Vasco $n^{0}$ 17/1994, art. 2.2 del Real Decreto-ley $n^{\circ}$ 5/1996, art. 2.2 de la Ley $n^{\circ} 7 / 1997$ (2004): 21 de octubre de 2004, sentencia $n^{\circ}$ 178/2004, ECLI:ES:TC:2004:178.

Tribunal Constitucional Español, recurso de inconstitucionalidad $\mathrm{n}^{\mathrm{o}}$ 3372/96, promovido por Alejandro Trigo Morterero contra los artículos. $4,5,6,7,8,9,10,11,12,13,14$, disposición adicional segunda y disposición final primera, párrafo tercero, del Real Decreto-ley $n^{0} 7 / 1996$, de 7 de junio, sobre medidas urgentes de carácter fiscal y de fomento y liberalización de la actividad económica (2005): 7 de julio de 2005, sentencia no 189/2005, ECLI:ES:TC:2005:189.

Tribunal Constitucional Español, recursos de inconstitucionalidad $\mathrm{n}^{\circ}$ 5014-2000, 5053-2000, 5056-2000 y n ${ }^{0}$ 5061- 2000 interpuestos por los Gobiernos de la Generalidad de Cataluña, del Principado de Asturias, de Aragón y de la Junta de Comunidades de Castilla-La Mancha, contra los artículos 7 y 8, y las disposiciones transitoria y final segunda del Real Decreto-ley $n^{0} 7 / 2000$, de 23 de junio, de medidas urgentes en el sector de las telecomunicaciones (2005): 15 de diciembre de 2005, sentencia $\mathrm{n}^{\mathrm{O}}$ 332/2005, ECLI:ES:TC:2005:332.

Tribunal Constitucional Español, recursos de inconstitucionalidad, acumulados $\mathrm{n}^{0}$ 4781-2002 y $\mathrm{n}^{0}$ 4915-2002 interpuestos por el Consejo de Gobierno de la Junta de Andalucía y Procurador de los Tribunales don Roberto Granizo Palomeque (2007): 28 de marzo de 2007, sentencia n ${ }^{\circ}$ 68/2007, ECLI:ES:TC:2007:68. 
Tribunal Constitucional Español, recurso de inconstitucionalidad $\mathrm{n}^{\mathrm{o}}$ 71-2001, Consejo de Gobierno de la Comunidad Autónoma de Andalucía contra el artículo único, cardinales uno, dos y tres, del Real Decreto-ley $n^{o}$ 9/20oo, de 6 de octubre, de modificación del Real Decreto Legislativo $n^{o}$ 1302/1986, de evaluación de impacto ambiental (2012): 13 de enero de 2012, sentencia $\mathrm{n}^{0}$ 1/2012, ECLI:ES:TC:2012:1.

Tribunal Constitucional Español, recurso de inconstitucionalidad $\mathrm{n}^{\circ}$ 4247-2002, Grupo Parlamentario Socialista en el Congreso contra La Ley $n^{0}$ 2/2002 (2013): 5 de junio de 2013, sentencia $n^{0}$ 132/2013, ECLI:ES:TC:2013:132.

Tribunal Constitucional Español, recurso de inconstitucionalidad $\mathrm{n}^{\circ}$ 3931-2013, Grupo Parlamentario Socialista en relación con el Real Decreto-Ley $n^{0}$ 6/2O13 (2015): 5 de febrero de 2015, sentencia $n^{0}$ 12/2015, ECLI:ES:TC:2015:12.

Tribunal Constitucional Español, recurso de inconstitucionalidad $\mathrm{n}^{\circ}$ 5099-2014, Grupo Parlamentarios Socialista, IU, ICV-EUiA, CHA: La Izquierda plural; y Unión Progreso y Democracia, contra el Real Decreto-leyn ${ }^{o}$ 8/2014 (2015): 24 de septiembre de 2015, sentencia ${ }^{0}$ 199/2015, ECLI:ES:TC:2O15:199.

Tribunal Constitucional Español, recurso de inconstitucionalidad $\mathrm{n}^{\circ} 45^{28-}$ 2012, Consejo de Gobierno de la Junta de Andalucía contra los arts. 2, 3, 4, 5, 6 Uno, Dos, Tres y Cuatro, 7 y Disposición Final Primera del Real Decreto-Ley $n^{0}$ 14/2012 (2016): 18 de febrero de 2016, sentencia $n^{0}$ 26/2016, ECLI:ES:TC:2016:26.

Tribunal Constitucional Español, recurso de amparo $\mathrm{n}^{0}$ 4703-2012, Pedro María Gragera de Torres y 326 personas más contra el Auto de la Sección Séptima de la Sala de lo Contencioso-Administrativo del Tribunal Supremo, de 30 de mayo de 2011 y Real Decreto $n^{0}$ 1717/2010, de 17 de diciembre (2016): 28 de abril de 2016, sentencia $n^{\circ}$ 83/2016.

Tribunal Constitucional Español, recurso de inconstitucionalidad n ${ }^{\circ} 6524-$ 2014, Grupos Parlamentarios Socialista; IU, ICV-EUIA, CHA: La Izquierda Plural; y Unión, Progreso y Democracia, en relación con el artículo 2.1 del Real Decreto-ley $n^{\circ}$ 10/2014 (2016): 7 de julio de 2016, sentencia ${ }^{\circ}$ 126/2016. 
Tribunal Constitucional Español, recurso de inconstitucionalidad $\mathrm{n}^{\circ} 3925^{-}$ 2015, Grupo Parlamentario Socialista en el Congreso contra el art. 1.1 del Real Decreto-ley $n^{\circ} 7 / 2015$ (2016): 6 de octubre de 2016, sentencia $n^{\circ}$ 169/2016.

Tribunal Constitucional Español, recursos de inconstitucionalidad $\mathrm{n}^{\mathrm{o}}$ 7848-2014, $\mathrm{n}^{0} 7874-2014 \mathrm{y} \mathrm{n}^{\mathrm{0}} 21-2 \mathrm{O} 15$, acumulados, interpuestos por el Parlamento de Cataluña, el Gobierno de la Generalitat de Cataluña y más de cincuenta diputados del Grupo Parlamentario Socialista del Congreso en relación con el Real Decreto-ley $n^{0}$ 13/2014 (2017): 21 de diciembre de 2017, sentencia $\mathrm{n}^{\mathrm{O}} 152 / 2017$. 